\title{
OPEN
}

\section{Publisher Correction: Localization of RalB signaling at endomembrane compartments and its modulation by autophagy}

\author{
Manish Kumar Singh ${ }^{1,2}$, Alexandre P. J. Martin ${ }^{1,2}$, Carine Joffre $\mathbb{1}^{3}{ }^{3}$, Giulia Zago ${ }^{1,2}$, \\ Jacques Camonis $^{1,2}$, Mathieu Coppey ${ }^{1,4}$ \& Maria Carla Parrini ${ }^{1,2}$
}

Correction to: Scientific Reports https://doi.org/10.1038/s41598-019-45443-1, published online 20 June 2019

In the original version of this Article, the author Manish Kumar Singh was incorrectly indexed. This error has now been corrected.

\begin{abstract}
(i) Open Access This article is licensed under a Creative Commons Attribution 4.0 International License, which permits use, sharing, adaptation, distribution and reproduction in any medium or format, as long as you give appropriate credit to the original author(s) and the source, provide a link to the Creative Commons license, and indicate if changes were made. The images or other third party material in this article are included in the article's Creative Commons license, unless indicated otherwise in a credit line to the material. If material is not included in the article's Creative Commons license and your intended use is not permitted by statutory regulation or exceeds the permitted use, you will need to obtain permission directly from the copyright holder. To view a copy of this license, visit http://creativecommons.org/licenses/by/4.0/.
\end{abstract}

(C) The Author(s) 2019

\footnotetext{
${ }^{1}$ Institut Curie, Centre de Recherche, Paris Sciences et Lettres Research University, 75005, Paris, France. ${ }^{2}$ ART group, Inserm U830, 75005, Paris, France. ${ }^{3}$ Centre de Recherches en Cancérologie de Toulouse (CRCT), Inserm UMR1037, Toulouse, France. ${ }^{4}$ LOCCO group, UMR168, 75005, Paris, France. Correspondence and requests for materials should be addressed to M.C.P. (email: maria-carla.parrini@curie.fr)
} 